\title{
Evaluation of the Potential Side-Effects of Novaluron on the Shrimp Palaemon adspersus: Moulting Hormone Profile, Cuticle Secretion and Chitin Contents
}

\author{
Hinda Berghiche ${ }^{1}$, Hamida Benradia ${ }^{2}$, Noureddine Soltani ${ }^{1}$ \\ ${ }^{1}$ Department of Biology, Faculty of Sciences, Badji-Mokhtar University of Annaba, Annaba, Algeria \\ ${ }^{2}$ Department of Biology, University of Bordj Bou-Arreridj, Bordj Bou-Arreridj, Algeria
}

Email address:

hindabentoubal@hotmail.ca (H. Berghiche)

\section{To cite this article:}

Hinda Berghiche, Hamida Benradia, Noureddine Soltani. Evaluation of the Potential Side-Effects of Novaluron on the Shrimp Palaemon adspersus: Moulting Hormone Profile, Cuticle Secretion and Chitin Contents. International Journal of Environmental Monitoring and Analysis. Vol. 6, No. 4, 2018, pp. 116-124. doi: 10.11648/j.ijema.20180604.11

Received: September 12; Accepted: October 30, 2018; Published: November 28, 2018

\begin{abstract}
The leaching of a large amount of pollutants derived from agricultural and domestic activities (fertilizers, pesticides, detergents) might contaminate especially the aquatic environments affecting several non-target aquatic organisms such as crustacean species. The current study aimed to evaluate under laboratory conditions the potential side-effects of novaluron $(20 \%$ Wettable Powder), a potent benzoylurea derivative insecticide on mosquito larvae, against a non-target shrimp, Palaemon adspersus Rathke, 1837 (Decapoda, Palaemonidae). This species is abundant in the lagoon El-Mellah (Northeast Algeria) and a relatively important species for the local fishery industry. The compound was tested at two concentrations $(0.91 \mathrm{mg} / \mathrm{L}$ and $4.30 \mathrm{mg} / \mathrm{L})$ corresponding respectively to the $\mathrm{LC}_{50}$ and $\mathrm{LC}_{90}$ determined against fourth-instar larvae of Culiseta longiareolata (Diptera, Culicidae). The newly ecdysed adult shrimps were exposed for 15 days, i.e. stage A until D during a moult cycle. Under normal conditions, changes in hemolymphatic ecdysteroid concentrations during the molting cycle presented a peak at stage $\mathrm{D}$, just before the ecdysis while in the treated series, we note an increase in hemolymphatic ecdysteroid concentrations at stages $\mathrm{C}$ and $\mathrm{D}$ and an absence of the peak as compared to the controls. Histological observations of integuments revealed that novaluron caused a significant reduction in thickness of the new cuticle at its $\mathrm{LC}_{50}$ and an inhibition of the new cuticle secretion at its $\mathrm{LC}_{50}$. The determination of chitin amounts, showed that exposure of shrimps to novaluron resulted in a significant decrease of values at all molting stages with a dose-response manner in comparison to controls. Thus, the overall data confirm the primary mode of action of novaluron on chitin. This insecticide can present secondary effects on this non-target shrimp species commercially important for the local economy.
\end{abstract}

Keywords: Toxicology, Novaluron, Palaemon adspersus, Ecdysteroids, Cuticle, Chitin

\section{Introduction}

Conventional pesticides are widely used in crop production and very effective against target organisms [1]. So, they are known to make risks and impacts on human health and environment [2]. In this context, several institutions have extensively searched alternatives such as insect growth disruptors (IGDs) with specific mode of action on insect and lower toxicity against non-target organisms than conventional insecticides [3, 4]. The IGDs compounds can be grouped according to their mode of action, as follows: substances that interfere with the action of insect hormones (i.e. juvenile hormones, ecdysteroids) and chitin synthesis inhibitors (i.e. of cuticle formation. Among these they are several classes of the chitin synthesis inhibitors, such as pyrimidine-nucleoside peptides, benzoylurea, oxazolines, thiazolidines, tetrazines, thiadiazines, thiophthalimides and certain chromo- and fluorophores [5]. The benzoylurea compounds prevent the formation of chitinous structures and interfere with the molt process which hampers normal development of exoskeleton in many insect orders [6]. During the last decades, an intensive search for more potent benzoylurea derivatives from the prototype compound, diflubenzuron [7], has resulted in synthesis of several 
analogues, such as triflumuron [8], chlorfluazuron [9], teflubenzuron [10], hexaflumuron [11], flufenoxuron [12], lufenuron [13] and more recently, novaluron [14]. Previously, it has been shown that diflubenzuron could affect the cuticle by reducing the thickness and altering their structure [15] due to a decreased amount of chitin in Penaeus kerathurus [16]. An HPLC analysis for residues of diflubenzuron, and has reported that the compound present a low stability in sea water under laboratory conditions [15]. More recently, diflubenzuron affect the levels of different biochemical constituents as proteins, lipids, carbohydrates in hemolymph and muscle during a moulting cycle [17].

Novaluron is a chitin synthesis inhibitor, belonging to the class of benzoylurea insecticide with excellent activity against several important insect pests [18] with a high toxicity level and effectiveness against several mosquito larvae as, Culiseta longiareolata [19] Aedes aegypti [20] and Culex pipiens [21]. It was designated a reducedrisk/organophosphorus alternative as it exhibit low acute mammalian toxicity and no significant subchronic effects in mammals $[22,23,24]$. So, according to these agencies, novaluron was considered a low risk to the environment and non target organisms. Its use might contaminate rivers which diverse their pollutants into the lakes of El kala (Northeast Algeria) and the Annaba gulf. Therefore, in the present study, we investigate the impact of this compound on a non-target organism, shrimp Palaemon adspersus Rathke, 1837 (Decapoda, Palaemonidae) abundant in the lagoon El-Mellah
(Northeast Algeria) and a relatively important species for the local fishery industry. The compound was added to the rearing seawater of newly-ecdysed adult shrimps during a molt cycle. We examine its effects on ecdysteroid profile, cuticle secretion and chitin contents. The data obtained show that this insecticide can present secondary effects on this nontarget shrimp species.

\section{Materials and Methods}

\subsection{Collection and Rearing of Shrimps}

Palaemon adspersus Rathke, 1837 (Decapoda, Palaemonidae) were collected from the lagoon El-Mellah (Northeast Algeria), in the channel that leads to the Mediterranean Sea (Figure 1). This site is far from any source of pollution and expected as a relatively clean site away from pollution sources $[25,26]$. Shrimps were transported to the laboratory alive and reared in laboratory conditions by maintaining them in glass aquaria $(100 \times 60 \mathrm{x}$ $80 \mathrm{~cm}$ ) filled with sea water (salinity $37 \mathrm{psu}$; temperature 22 $25^{\circ} \mathrm{C}$; photoperiod $14 \mathrm{~h}$ of light). Filtration is performed by water filter having a flow rate of $1801 / \mathrm{h}$ (Rena 225). The animals were daily fed with fresh mussels distributed in the afternoon. Prior to exposure, shrimps were acclimated to laboratory conditions for a week. Shrimps with of similar size (length: $25 \mathrm{~mm}$ and weight: $850 \mathrm{mg}$ ) were used in the experiment.

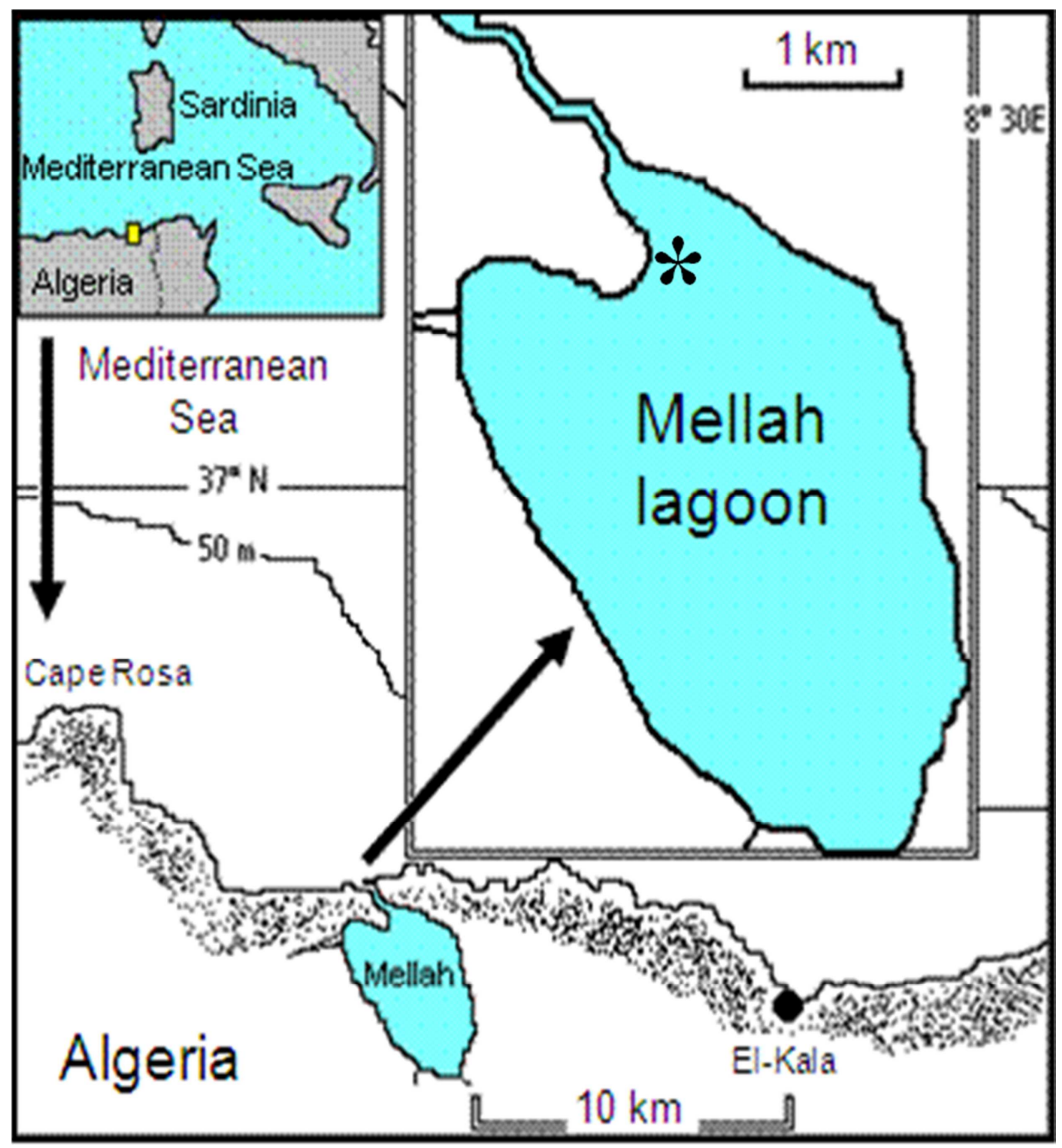

Figure 1. Location of the sampling site in the Mellah lagoon (Northeast Algeria). [27] *: constriction zone of the channel with Mediterranea. 


\subsection{Shrimp Datation}

The decapod Crustaceans moult cycle is divided into five key stages: A (early postmolt), B (late postmolt), C (intermolt) and $\mathrm{D}$ (premolt) and moulting (E). The datation was made according to the method of [28], based on morphogenesis be at the uropod. This method is simple, fast and efficient. Under these conditions, $P$. adspersus has a molt cycle of 20 days with $20 \%$ for $\mathrm{A}+\mathrm{B}, 25 \%$ for $\mathrm{C}$, and $65 \%$ for $\mathrm{D}$.

\subsection{Insecticide and Treatment}

Novaluron (wettable powder $20 \%$ active ingredient), was kindly provided by Pr. G. Smagghe (Ghent University, Belgium) (Figure 2). The compound was added to the rearing sea water at two final concentrations $(0.91 \mu \mathrm{g} / \mathrm{L}$ and $4.30 \mathrm{mg} / \mathrm{L})$ corresponding respectively to the $\mathrm{LC}_{50}$ and $\mathrm{LC}_{90}$ obtained with respect to the fourthstage larvae Culiseta longiareolata (Diptera, Culicidae) [19]. Newly-ecdysed adult shrimps (0-8 h old) were exposed continuously to treatment. Control shrimps were reared in sea water only. Samples (hemolymph, cephalothorax and uropod) were collected from each shrimp at different stages of molt cycle (A, B, C, and D) in control and treated series.

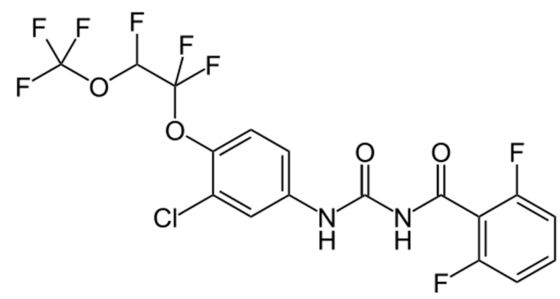

Figure 2. Molecular structure of novaluron.

\subsection{Enzyme Immunoassay of Ecdysteroids}

Each sample of hemolymph $(3 \mu \mathrm{l})$ was extracted with methanol by sonication (2-3 $\mathrm{min}$ ). After centrifugation (5000 g, $10 \mathrm{~min}$ ), the supernatants were taken and evaporated $\left(60^{\circ} \mathrm{C}\right)$. Each sample was resuspended in $500 \mu \mathrm{l}$ of phosphate buffer $(0.1 \mathrm{M} ; \mathrm{pH} 7.4)$ and individually analyzed by an enzyme-immunoassay (EIA) according to the method of [29] modified by [30] and previously described [31] using a conjugate of 20-hydroxyecdysone coupled to peroxidase as the enzymatic tracer, tetramethylbenzidine as the colour reagent and a rabbit $\mathrm{B}$ polyclonal antibody. Absorbance was read at $630 \mathrm{~nm}$ and data was expressed in pg $20 \mathrm{E} / \mu \mathrm{l}$ of hemolymph. The tracer and antibodies were kindly provided by Dr. J. P. Delbecque (CNRS, University of Bordeaux I, France) and C. Blaise (Pierre and Marie Curie University, Paris, France), respectively.

\subsection{Histological Procedure}

Uropods were sampled at different stages of moult cycle (A-D), in control and novaluron-exposed series and fixed in formol $(10 \%)$. After dehydration in serial washes of graded ethanol the samples were passed through three washes in xylene before were embedded in paraffin as according to [32]. Transverse sections of uropod $(4 \mu \mathrm{m})$ were made using a Leica RM2125T (Leica Microsystems Nussloch GmbH, Wetzlar, Germany) manual rotary microtome and stained with hematoxylin-eosin. Observations were made in a Leica DM500 microscope equipped with a Leica ICC50 HD camera and the thickness of different cuticle was measured with Las EZ Leica software in each series.

\subsection{Chitin Quantification}

Chitin quantification in peripheral integument was performed following the procedure of, previously described [33]. Chitin content was determined at different stages during the molting cycle in control and treated series by quantification of glucosamine derivatives obtained by deacetylation, depolymerisation and deamination of $\mathrm{N}$-acetyl-glucosamine polymer. Briefly, chitin is subjected to an alkaline digestion with $\mathrm{KOH}(14 \mathrm{M})$ at $130^{\circ} \mathrm{C}$ to deacetylate the chitin of each sample, thus forming chitosan. Then a solubilized chitosan solution is depolymerized by $\mathrm{NaNO}_{2}(10 \%)$ and $\mathrm{KHSO}_{4}(10 \%)$ to liberate the amine residues from the glucosamine, forming a soluble aldehyde. Theses aldehydes generated in a reaction with $\mathrm{NH}_{4} \mathrm{SO}_{3} \mathrm{NH}_{2}(12.5 \%)$ and with further addition of MBTH and $\mathrm{Fe}^{+3}$ a blue coloration. Absorbance was read at $650 \mathrm{~nm}$ and chitin content was expressed as glucosamine equivalents, according to a standard curve made with glucosamine. Weight of cuticle was determined, before chitin quantification to normalize the results.

\subsection{Statistical Analysis}

Statistical analyses were performed using the Prism software version 6.01 for Windows (GraphPad Software Inc., www.graphpad.com). Results are represented as mean \pm standard deviation (SD). The homogeneity of variances was checked by Bartlett's test. The linear and non-linear regression was used to establish the reference curves for the determination of chitin and ecdysteroids contents, respectively. Data were subjected to two-way analysis of variance (ANOVA) followed by a post-hoc HSD Tukey test or to a Student's $t$ test at $\mathrm{p}<0.05$.

\section{Results}

\subsection{Effect of Novaluron on Ecdysteroid Contents}

Under normal conditions of $P$. adspersus, the titers of hemolymphatic ecdysteroids increased during the molt cycle to reach a peak at stage $\mathrm{D}$, just before the ecdysis. The value recorded at the beginning (stage A) and the end (stage D) were $33.48 \pm 3.81$ and $115.57 \pm 2.51 \mathrm{pg} / \mu \mathrm{l}$, respectively. In treated series by novaluron at the two tested concentrations $\left(\mathrm{LC}_{50}\right.$ and $\left.\mathrm{LC}_{90}\right)$, we note the absence of the peak of ecdysteroids at stage $D$ and a significant increase $(p<0.01)$ at stages $\mathrm{B}, \mathrm{C}$ and $\mathrm{D}$ as compared to control series. The values recorded with the $\mathrm{LC}_{90}$ were $93.76 \pm 1.50$ at the postmolt 
(stage B), $119.63 \pm 2.12$ at the intermoult (stage C) and $137.44 \pm 2.87 \mathrm{pg} / \mu \mathrm{l}$ at the premolt (stage D) (Table 1). In addition, ANOVA revealed significant effects of concentration $\left(\mathrm{F}_{2,24}=16.02 ; \mathrm{p}<0.0001\right)$, stage $\left(\mathrm{F}_{3,24}=124.8\right.$; $\mathrm{p}<0.0001)$ and interaction concentration/stage $\left(\mathrm{F}_{6,24}=2.06\right.$; $\mathrm{p}<0.0001)$.

Table 1. Effect of novaluron $\left(L C_{50}, L C_{90}\right)$ on the hemolymphatic ecdysteroids titer (pg/ $\mu$ l equi $\left.20 E\right)$ during the molt cycle of $P$. adspersus (mean $\pm S D$, $\left.n=4-7\right)$.

\begin{tabular}{llll}
\hline Stages & Control & Novaluron (LC $\mathbf{5 0}_{\mathbf{5 0}}$ ) & Novaluron (LC90) \\
\hline \multirow{2}{*}{$\mathrm{A}$} & $33.48 \pm 3.81 \mathrm{a}$ & $36.41 \pm 4.40 \mathrm{a}$ & $30.57 \pm 2.15 \mathrm{a}$ \\
& $\mathrm{A}$ & $\mathrm{A}$ & $\mathrm{A}$ \\
$\mathrm{B}$ & $68.57 \pm 9.13 \mathrm{a}$ & $90.84 \pm 3.50 \mathrm{~b}$ & $93.76 \pm 1.50 \mathrm{~b}$ \\
& $\mathrm{~B}$ & $\mathrm{~B}$ & $\mathrm{~B}$ \\
$\mathrm{C}$ & $83.77 \pm 8.53 \mathrm{a}$ & $116.59 \pm 7.20 \mathrm{~b}$ & $119.63 \pm 2.12 \mathrm{~b}$ \\
& $\mathrm{~B}$ & $\mathrm{C}$ & $\mathrm{C}$ \\
$\mathrm{D}$ & $115.57 \pm 2.51 \mathrm{a}$ & $139.23 \pm 1.07 \mathrm{~b}$ & $137.44 \pm 2.87 \mathrm{~b}$ \\
\hline
\end{tabular}

Different capital letters indicate a significant difference between stages of the same series; different small letters indicate a significant difference between control and treated series of the same stage $(p>0.05)$.

\subsection{Effect of Novaluron on Cuticle Secretion}

In control series, the thickness of $P$. adspersus cuticle increased progressively during the three first stages (A, B, C) and decreased at the end of molt cycle (stage D) (Figure 3A). Cuticle thickness measurement showed that treatment with novaluron at the two tested concentrations $\left(\mathrm{LC}_{50}, \mathrm{LC}_{90}\right)$, reduced significantly $(\mathrm{p} \leq 0.0001)$ the thickness of the old cuticle with a dose-response effect as compared to controls. ANOVA indicated significant effects of concentration $\left(F_{2,28}\right.$ $=35.82 ; \mathrm{p}<0.0001)$, stage $\left(\mathrm{F}_{2,28}=47.3 ; \mathrm{p}<0.0001\right)$ and interaction concentration/stage $\left(\mathrm{F}_{4,28}=4.37 ; \mathrm{p}=0.0035\right)$. As shown in figure $3 \mathrm{~B}$, the thickness of new cuticle was $3.31 \pm$ $0.28 \mu \mathrm{m}$ at stage $\mathrm{D}$ in control series. Novaluron-treatment decreased significantly $(\mathrm{p} \leq 0.0001)$ the thickness of this new cuticle $(1.54 \pm 0.48 \mu \mathrm{m})$ with $\mathrm{LC}_{50}$ and inhibited completely the secretion of the new cuticle with $\mathrm{LC}_{90}$. The observations histological sections showed a reduction in the thickness of cuticles with both concentrations $\mathrm{LC}_{50}$ and $\mathrm{LC}_{90}$ without modifications in the structure appearance (Figure 4).

\section{A}
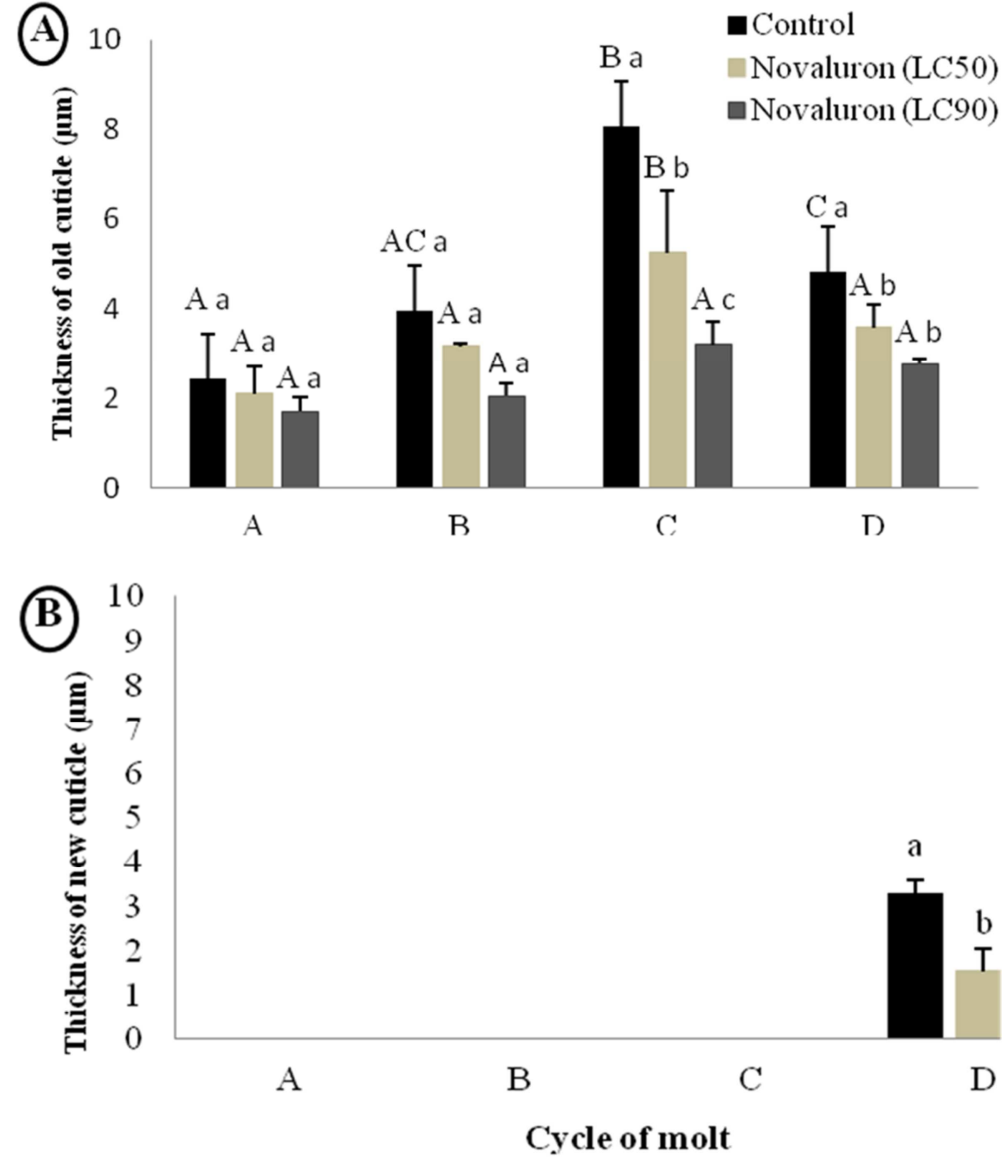

Figure 3. Effect of novaluron $\left(L C_{50}, L C_{90}\right)$ on the cuticle thickness measurement ( $\left.\mu m\right)$ of old $(A)$ and new cuticle $(B)$ in $P$. adspersus during the molt cycle $(m \pm$ $S D, n=4-5$ ). 
Different capital letters above values indicate a significant difference between stages of the same series; different small letters indicate a significant difference between control and treated series of the same stage $(p>0.05)$.
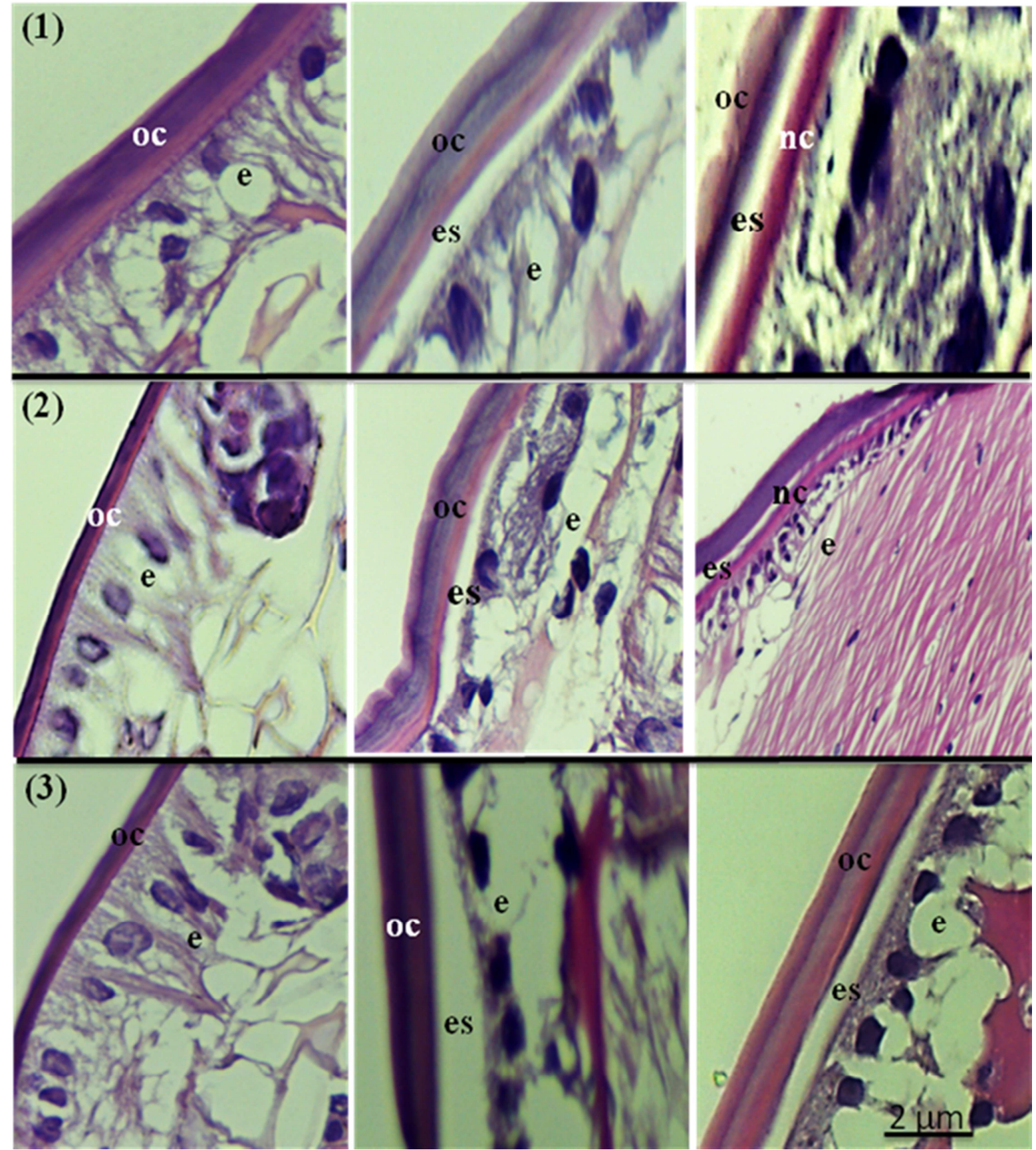

Figure 4. Transverse sections of cuticle in control and treated series of $P$. adspersus during the molt cycle. (1) Control: stages A-B, C, D; (2) Novaluron LC 50 : stages $A-B, C, D$; (3) Novaluron $L C_{90}$ : stages $A-B, C$, D. (e: epidermis; oc: old cuticle; nc: new cuticle; es: exuvial space).

\subsection{Effect of Novaluron on Chitin Contents}

The measurement of chitin contents in control series showed a progressive increase from stage $\mathrm{A}$ until stage $\mathrm{C}$ to reach a maximum of $150.37 \pm 6.02 \mu \mathrm{g} / \mathrm{mg}$ and decreased thereafter at stage D $(104.22 \pm 8.45 \mu \mathrm{g} / \mathrm{mg})$. Novaluron treatment $\left(\mathrm{LC}_{50}\right.$ and $\left.\mathrm{LC}_{90}\right)$, resulted in a significant $(\mathrm{p} \leq$ $0.0001)$ decrease in the chitin content with a dose-response relationship comparatively to controls. The values recorded with the $\mathrm{LC}_{50}$ were $97.82 \pm 7.51 \mu \mathrm{g} / \mathrm{mg}$ at the stage $\mathrm{C}$ and $87.25 \pm 8.88$ at stage D. For, the $\mathrm{LC}_{90}$ the values decreased to $76.44 \pm 4.63 \mu \mathrm{g} / \mathrm{mg}$ and $49.79 \pm 4.38 \mu \mathrm{g} / \mathrm{mg}$, at stages $\mathrm{C}$ and $\mathrm{D}$, respectively (Table 2). ANOVA showed significant effects of concentration $\left(\mathrm{F}_{2,52}=465.8 ; \mathrm{p}<0.0001\right)$, stage $\left(\mathrm{F}_{3,52}=\right.$ 216.4; $\mathrm{p}<0.0001)$ and interaction concentration/stage $\left(\mathrm{F}_{6,52}=\right.$ 40.77; $<<0.0001)$. 
Table 2. Effect of novaluron ( $\left.L C_{50}, L C_{90}\right)$ on the chitin content ( $\mu \mathrm{g}$ of glucosamine/mg tissue) during the molt cycle of $P$. adspersus (mean $\left.\pm S D, n=4-7\right)$.

\begin{tabular}{llll}
\hline Stages & Control & Novaluron $\left(\mathbf{L C}_{\mathbf{5 0}}\right)$ & Novaluron $\left(\mathbf{L C}_{\mathbf{9}}\right)$ \\
\hline \multirow{2}{*}{$\mathrm{A}$} & $71.12 \pm 1.92 \mathrm{a}$ & $73.03 \pm 4.23 \mathrm{a}$ & $48.51 \pm 10 \mathrm{~b}$ \\
& $\mathrm{~A}$ & $\mathrm{~A}$ & $\mathrm{~A}$ \\
$\mathrm{~B}$ & $101.71 \pm 4.57 \mathrm{a}$ & $85.43 \pm 2.10 \mathrm{~b}$ & $67.06 \pm 1.90 \mathrm{c}$ \\
& $\mathrm{B}$ & $\mathrm{B}$ & $\mathrm{B}$ \\
$\mathrm{C}$ & $150.37 \pm 6.02 \mathrm{a}$ & $97.82 \pm 7.51 \mathrm{~b}$ & $76.44 \pm 4.63 \mathrm{c}$ \\
& $\mathrm{C}$ & $\mathrm{C}$ & $\mathrm{C}$ \\
$\mathrm{D}$ & $104.22 \pm 8.45 \mathrm{a}$ & $87.25 \pm 8.88 \mathrm{~b}$ & $49.79 \pm 4.38 \mathrm{c}$ \\
\hline
\end{tabular}

Different capital letters indicate a significant difference between stages of the same series; different small letters indicate a significant difference between control and treated series of the same stage ( $p>0.05)$.

\section{Discussion}

The molting hormone (ecdysteroids) in crustacean as in other arthropods, play a crucial role in the control of growth, reproduction and embryogenesis $[34,35]$. The crustacean YO synthesizes from cholesterol as a precursor biosynthetic a greater diversity of ecdysteroids in the hemolymph [36, 37] depending on species such as, ecdysone, 3-dehydroecdysone (3dE), 25-deoxyecdysone (25dE) and 3-dehydro-25deoxyecdysone (3D25dE). Peripheral tissues convert these compounds to the active hormone: 20-hydroxyecdysone (20E) and ponasterone A (25-deoxy-20-hydroxyecdysone or $25 \mathrm{~d} 20 \mathrm{E}$ by cytochrome P-450 mono-oxygenases [37]. 20E and PoA are the major active ecdysteroids circulating in the hemolymph during the postmolt and intermolt stages, while $20 \mathrm{E}$ alone is the major ecdysteroid during premolt stage of decapods crustacean [38, 39, 40]. Ecdysteroid assays were performed in a number of decapod crustaceans in total extracts, hemolymph, ovaries or eggs using a high performance liquid chromatography (HPLC) (Baldaia et al. 1984), the radioimmunoassay [40] and an enzymeimmunological method [31].

In the current study, under normal conditions, hemolymphatic ecdysteroid titers determined by an enzyme immunoassay, vary throughout the molt cycle of $P$. adspersus. The titers of $20 \mathrm{E}$ are low during postmolt (stage $\mathrm{AB}$ ) and increased progressively in intermolt (stage C). A single peak was recorded in premolt (stage D). It coincides with the apolysis, which results from the destruction of the deep layers of the old cuticle and the beginning of the genesis of the new. In accordance with our results, total ecdysteroid titers in hemolymph vary over the molt cycle in a variety of crustacean species: Orchestia cavimana [40]; Penaeus vannamei [41]; P. kearathurus [31], and Callinectes sapidu [42]. Generally, in crustacean the titers of $20 \mathrm{E}$ is low during intermolt and postmolt; during premolt, concentration rise and reach a peak shortly before molting $[43,39]$.

The results obtained after treatment with novaluron, revealed an increase in hemolymphatic ecdysteroid titers with absence of the peak as compared to controls. The increase in hemolymph ecdysteroids is largely due to increased biosynthesis and conversion to active ecdysteroids. Novaluron is known to be very effective against several important insect pests [44, 45] and his bioactivity is typically much greater than diflubenzuron and teflubenzuron [14].
Indeed, different species of mosquitoes such as $A$. aegypti [46, 20]; Culex spp [47], A. albopictus, Anopheles albimanus, Anopheles pseudopunctipennis and Culex quinquefasciatus [48], Culiseta longiareolata [19] and Culex pipiens [21] were highly susceptible to novaluron. Several works demonstrated an increase in biochemical constituents (carbohydrates, proteins, lipids) with inhibitors of chitin synthesis: lufenuron in schistocerca gregria [49], novaluron in Culex pipiens [21] and flufenoxuron in Schistocerca gregaria [50]. Similar results were observed with shrimp's $P$. kerathurus after treatment with diflubenzuron; this compound caused an increase in the amounts of carbohydrates, lipids and proteins in the hemolymph at the end of the molting cycle (stage D) in P. kerathurus [17].

Histological study showed a progressive increase of the cuticle thickness during the three first stages (A, B, C) and a decrease at the end of the molt cycle (stage D) in controls. Cuticle thickness measurement showed that novalurontreatment affect the cuticle secretion with a reduction in the thickness of the old cuticle with a dose-response manner as compared to control groups and an inhibition of the new cuticle. The application of chitin synthesis inhibitors typically induces malformations of the cuticle and a significant reduction of chitin amounts [51]. These results showed that the novaluron develop a fragile cuticle unable to support the increased tension during the molting process and the increase in chitin content observed during our experiments may be related to an inhibition of. Indeed, benzoylurea do not directly interfere with catalytic reaction of chitin synthesis, but act on a postcatalytic step [52], blocking the postcatalytic step of chitin synthesis [53]. Our results are consistent with those commonly reported. Indeed, the derivatives of the benzoylurea interfere with the molting process by disrupting cuticle secretion via the chitin synthesis $[3,15,54]$. Also, ultrastructural analysis revealed abnormal deposition of procuticular layers in response to the treatment with benzoylurea as demonstrated in shrimp P. kerathurus [15], beetles [51].

Chitin a polymer of $N$-acetyl-b-D-glucosamine, is a major component of the arthropods cuticle. It constitutes up to $40 \%$ of the exuvial dry mass depending on the species and varies considerably with the different cuticle types even in a single organism [55]. Chitin is catalyzed by the chitin synthase enzyme from UDP-N-acetylglucosamine precursors [52]. The molting hormone (20E) acts on expression and activity 
of chitinolytic enzymes, such as chitobiase and chitinase which are involved in exoskeleton degradation and recycling during ecdysis in arthropods [56]. In our experiment, the measurement of chitin contents in controls showed a progressive increase from stage A until stage $\mathrm{C}$ and decreased at stage $\mathrm{D}$. These variations were correlated with principal events of cuticle deposition. According to [15], the chitin content varied between 66 and $72 \%$ during molting cycle in shrimp P. kerathurus. The same authors reported an incorporation of two precursors, D-[3- $\left.{ }^{3} \mathrm{H}(\mathrm{N})\right]$-glucose and $\mathrm{N}$-acétyl-D-[1-3H]-glucosamine (NAGA) in the postmolt (stage A and B) leading to the secretion of endocuticle, followed by a decrease at the intermolt (stage C) (where the secretion of cuticle is complete) and the least content of incorporation of the two precursors is noted in premolt (stage D) where exocuticle secretion is completed. Novalurontreatment increased significantly the chitin content with a dose-response effect probably by inhibit of the incorporation of sugars into the growing chitin chain. This is in accordance with a previous report made with diflubenzuron another chitin synthesis inhibitor on P. kerathurus [19].

\section{Conclusion}

In conclusion, the results obtained in this study were the first demonstrating that novaluron exerted negative effects in a shrimp species. It can increase the amounts of ecdysteroids and disrupt the chitin content causing inhibition of cuticular secretion in a non-target organism $P$. adspersus. These effects could be explained either by a blockage of transport and incorporation of the biosynthetic precursor of chitin, Nacetyl-D-glucosamine (GlcNAc), or directly by inhibition of chitin synthesis. However, these mechanisms of action remained unclear and new experimental approaches are needed. Given the biochemical composition of their cuticle, the crustaceans can be the potential targets of these benzoylurea derivatives.

\section{Acknowledgements}

This research was supported by the National Fund for Scientific Research of Algeria (Laboratory of Applied Animal Biology to Pr. N. Soltani) and the Ministry of Higher Education and Scientific Research of Algeria (CNEPRU project F 011201440046, Dr. H. Berghiche). Authors are gratefull to Pr. G. Smagghe 'Ghent University, Belgium) for the sample of novaluron and Pr. S. Kilani-Morakchi for the protocol of chitin analysis.

\section{References}

[1] Bruce TJA (2010) Tackling the threat to food security caused by crop pests in the new millennium. Food Sec 2: 133-141.

[2] Aktar MW, Sengupta D, Chowdhury A (2009) Impact of pesticides use in agriculture: their benefits and hazards. Interdiscipl Toxicol 2 (1): 1-12.
[3] Dhadialla TS, Retnakaran A, Smagghe G (2010) Insect growth and development disturbing insecticides. In: Gilber, $L$. I., Gill, S. S. (Eds). Insect Control.: Elsevier p. 121-184.

[4] Pener MP, Dhadialla TS (2012) An Overview of Insect Growth Disruptors; Applied Aspect. Adv Insect Physiol 43. ISBN 978-0-12-391500-9.

[5] Merzendorfer H (2013) Chitin synthesis inhibitors: old molecules and new developments. Insect Sci 20: 121-138.

[6] Muthukrishna S, Merzendorfer H, Arakan Y, Kramer KJ (2012) Chitin metabolism in insects. (ed. L. I. Gilberts). Comprehensive Molecular Insect Science. London: Academic Press; p. 193-235.

[7] Van Daalen, JJ, Meltzer J, Mulder R, Wellinga K (1972) A selective insecticide with a novel mode of action. Naturwissenschaften 59: 312-313.

[8] Hamman I, Sirrenberg W (1980) Laboratory evaluation of SIR 8514 , a new chitin synthesis inhibitor of the benzoylated urea class. Pflanzenschutz-Nachr Bayer 33: 1-34.

[9] Haga T, Tobi T, Koyanagi T, Nishiyama R (1982) Structure activity relationships of a series of benzoylpyridyloxyphenylurea derivatives. In 5 th International Congress of Pesticide Chemistry (IUPAC). Kyoto p7.

[10] Becher HM, Becker P, Prokic-Immel R, Wirtz W (1983) CME-134, a new chitin synthesis inhibiting insecticide. Proceeding of 10th International Congress of Plant Protection 1: 408-415.

[11] Sbragia RJ, Bishabri-Ershadi B, Risterink RH, Clilfford DP, Dutton R (1983) XRD-473, a new acylutea insecticide effective against Heliothis. Proceedings of British Crop Protection Conference on Pests and Diseases. Brighton, UK $1: 417-424$.

[12] Anderson M, Fisher JP, Robinson J (1986) Flufenoxuron-an acylurea acaricide/insecticide with novel properties. Proceedings of British Crop Protection Conference on Pests and Diseases. Brighton, UK p. 89-96.

[13] Hink WF, Drought DC, Barnett S (1991) Effect of an experimental systemic compound, CGA-184699, on life stage of the cat flea (Siphonaptera: Pulicidae). J Med Entomol. 28: 424-427.

[14] Ishaaya I, Yablonski S, Mendelson Z, Mansour Y, Horowitz AR (1996) Novaluron (MCW-275), a novel benzoylphenyl urea, suppressing developing stages of lepidopteran, whitefly and leafminer pests. Proceedings of the Brighton Crop Protection Conference, Pests and Diseases 3: 1013-1020.

[15] Morsli SM, Soltani N (2003) Effect of an inhibitory insecticide of the synthesis of chitin, diflubenzuron on the cuticle of the shrimp Penaeus kerathurus. J recherch oceano 28 (1/2): 85-88.

[16] Soltani N, Lechekhab H, Smagghe G (2009) Impact of the insect growth regulator diflubenzuron on biochemical composition of cuticle of the shrimp Penaeus kerathurus. Comm Appl Biol Sci Ghent University, 74/1: 137-141.

[17] Morsli MS, Merad I, Khebbeb MEH, Soltani, N (2015) Potential hazards of a chitin synthesis inhibitor diflubenzuron in the shrimp Penaeus kerathurus: biochemical composition of the hemolymph and muscle during the molt cycle. Adv Environ Biol 9 (3): 518-525. 
[18] Cutler GC, Scott-Dupree CD, Tolman JH, Harris CR (2007) Field efficacy of novaluron for control of Colorado potato beetle (Coleoptera: Chrysomelidae) on potato. Crop Prot 26:760-767.

[19] Bouaziz A, Boudjelida H, Soltani N (2011) Toxicity and perturbation of the metabolite contents by a chitin synthesis inhibitor in the mosquito larvae of Culiseta longiareolata. Ann Biol Res 2 (3): 134-142.

[20] Farnesi LC, Brito JM., Linss JG, Pelajo-Machado M, Valle D, Rezende GL (2012) Physiological and morphological aspects of Aedes aegypti developing larvae: effects of the chitin synthesis inhibitor Novaluron. PLoS ONE 7, e30363.

[21] Djeghader NEH, Boudjelida H, Bouaziz A, Soltani N (2013) Biological effects of a benzoylphenylurea derivative (Novaluron) on larvae of Culex pipiens (Diptera: Culicidae). Adv App Sci Res 4 (4): 449-456.

[22] EPA (2001) Novaluron Pesticide Fact Sheet, US EPA Office of Prevention, Pesticides and Toxic Substances. p 4.

[23] FAO/WHO (2005) Joint FAO/WHO Meeting on Pesticide Residues, 20-29 September; Geneva, Food and Agriculture Organization of the United Nations, World Health Organization $\mathrm{p} 360$.

[24] PMRA (2006) Proposed Registration Decision - Novaluron, Health Canada's Pest Management Regulatory Agency, Report No. PRD2006-05.2006. p 108.

[25] Bendjama A, Morakchi K, Meradi H, Boukari A, Chouchane T, Belaabed BE, Djabri L (2011) Caracterisation des materiaux biologiques issus d'un ecosysteme naturel « pnek » situe au nord-est de l'algerie. J Soc Alger Chim 21 (1): 45-58.

[26] Mebarki R, Khebbeb MEH, Soltani N (2015) Biomonitoring of El Mellah Lagoon (Northeast, Algeria): Seasonal Variation of Biomarkers in Cerastoderma glaucum (Mollusc, Bivalvia). JEZS 3 (4): 408-413.

[27] Draredja, B., Melouah, K, Beldi, H., Benmars, S (2012) Diversité de la macrofaune benthique de la lagune Mellah (Parc National, El-Kalpa, Algérie Nord-Est). Bull. Soc. Zool. Fr, 137(1-4): 73-86.

[28] Robertson NL, Bray W, Leung-Trujillo J \& Lawrence A (1987) Practical molt staging of Penaeus setiferus and Penaeus stylirostris. J Worl Aquacul Soc 18 (3): 180-185.

[29] Porcheron P, Oberlander H, Leach CE (1988) Ecdysteroid regulation of amino sugar uptake in a lepidopteran cell line derived from imaginal discs. Arch Insect Biochem Physiol. 7:145-155.

[30] De Reggi ML, Pitoizet N, Gharib B \& Delbecque JP (1992) New enzyme immunoassay for ecdysteroids using peroxydase enzyme and polyclonal or monoclonal antibodies. Xth Ecdysone Workshop, 6-7 th April; Leverpool p 91.

[31] Soltani N, Bezzazel N (2002) Profile of ecdysteroids haemolymph and correlations with secretion cuticular during a cycle of molt shrimp Penaeus kerathurus. $J$ de Recher Océano 27 (34): 226-231.

[32] Martoja R \& Martoja M (1967) Initiation aux techniques de l'histologie animale. Masson pp 345.

[33] Bensbaa F., Kilani-Morakchi S., Aribi N. \& Soltani N (2015) Evaluation of pyriproxyfen, a juvenile hormone analog, on
Drosophila melanogaster: insecticidal activity, ecdysteroid content and cuticle formation. Eur J Entomol 112 (4): 625-631.

[34] Subramoniam T (2000) Crustacean ecdysteroids in reproduction and embryogenesis. Comp Biochem Physiol Part C 125: 135-156.

[35] Chang, ES, Mykles DL (2011) Regulation of crustacean molting: A review and our perspectives. General Comp Endocrino172: 323-330.

[36] Gilbert LI and Rewitz KF (2009) The function and revolution of the Halloween genes in G Smagghe. (Ed). Ecdysone: structure and function: Springer science p231- 269.

[37] Mykles DLM (2011) Ecdysteroid metabolism in crustaceans. J Steroid Biochem Mol Biol 127: 196-203.

[38] Okumura T, Han CH, Suzuki Y, Aida K, Hanyu I (1989) Changes in hemolymph ecdysteroid levels during the molt cycle in the kumura prawn Penaeus japonicas. Nippon Suisan Gakk 55: 2091-2098.

[39] Yu XL, Chang ES, Mykles DL (2002) Caracterization of limb autotomy factor-proecdysis $\left(\mathrm{LAF}_{\mathrm{PRO}}\right)$ isolated from limb regenerates, that suspends molting in the land crab Gecarcinus lateralis, Biol Bull 202: 204-212.

[40] Cuzin-Roudy J, Strambi C, Strambi A, Delbecque JP (1989) Hemolymph ecdysteroids and molt cycle in males and females of Siriella armata M.- Edw. (Crustacea: Mysidacea): Possible control by the MI-ME X-organ of the eyestalk. Gen Comp Endoc 74:96-109.

[41] Blais C, Sefiani M, Toullec JY, Soyez D (1994) In vitro production of ecdysteroids by Y-organs of Penaeus vannamei (Crustacea, Decapoda). Correlation with hemolymph titers. Inverteb Repr Dev 26: 3-12.

[42] Chen B, Landry MR, Huang B, Liu H (2012) Does warming enhance the effect of microzooplankton grazing on marine phytoplankton in the ocean?. Limnol Oceanogr 57 (2): 519-526.

[43] Huberman A (2000) Shrimp endocrinology. rev Aquacul 191: 191-208.

[44] Nwankwo EN, Okonkwo NJ, Okafor EG (2011) Comparative studies on the larvicidal action of Novaluron (Mosquiron 100 EC) and Moringa oliefera Seed Oil against Aedes Aegypti. Int J Multi-Discip Res, Ethiopia 5 (1): 424-437.

[45] Fontoura NG, Bellinato DF, Valle D, Lima JB (2012) The efficacy of chitin synthesis inhibitor against fieid populations of organophophate resistant Aedes aegypti in Brazil. Mem Inst Oswaldo Cruz 107 (3): Print version ISSN 0074-0276.

[46] Mulla MS, Thavara U, Tawatsin A, Chompoosri J, Zaim M, $\mathrm{Su}$ TY (2003) Laboratory and field evaluation of novaluron, a new acylurea insect growth regulator, against Aedes aegypti (Diptera: Culicidae). J Vector Ecol 28: 241-254.

[47] Su TY, Mulla MS, Zaim M (2003) Laboratory and field evaluations of novaluron, a new insect growth regulator (IGR), against Culex mosquitoes. J Am Mosq Control Assoc 19: 408-418.

[48] Arredondo-Jiménez, Valdez-Delgado (2006) Effect of novaluron (Rimon $\left.{ }^{\circledR}\right) 10 \mathrm{EC}$ on the mosquitoes Anopheles albimanus, Anopheles pseudopunctipennis, Aedes aegypti albopictus and Culex quinquefasciatus from Chiapas, Mexico. Med Vet Entomol 20: 377-387. 
[49] Tanani MA, Ghoneim KS, Hamadah KS (2012) Comparative effects of certain IGRs on the carbohydrates of hymolymph and fat body of schistocercagregria: (Orthoptera: Acaracidae). Fla Entomol 95 (4): 928-935.

[50] Hamadah KH (2014). Metabolic activity of the chitin synthesis inhibitor, Flufenoxuron on the desert locust Schistocercagregaria (Orthoptera: Acaracidae). J Entomol Zool Stud 2 (1): 87-95.

[51] Merzendorfer H, Kim HS, Chaudhari SS, Kumari M, Specht CA, Butcher S, Brown SJ, Robert Manak J, Beeman RW, Kramer KJ, Muthukrishnan S (2012) Genomic and proteomic studies on the effects of the insect growth regulator diflubenzuron in the model beetle species Tribolium castaneum. Insect Biochem Mol Biol 42: 264-276.

[52] Merzendorfer H (2006) Insect chitin synthases: a review. JComp Physiol [B] 176: 1-15.

[53] Van Leeuwen T, Demaeght P, Osborne EJ, Dermauw W,
Gohlke S, Nauen R, Grbic M, Tirry L, Merzendorfer H, Clark RM (2012) Population bulk segregant mapping uncovers resistance mutations and the mode of action of a chitin synthesis inhibitor in arthropods. Proceedings of the National Academy of Sciences of the United States of America 1094: $407-4412$.

[54] Salokhe SG. Deshpanded SG. Pakhle K \& Maniyare AB (2013) IGR, Lufenuron, alters chitin and total soluble protein content of Aedes aegypti larvae during development of Aedes aegypti. Curr Sci 99 (9):1256-59.

[55] Kramer KJ, Dziadik-Turner C, Koga D (1985) Chitin metabolism in insects. Comprehensive Insect Physiology, Biochemistry, and Pharmacology. (eds. G. A. Kerkut \& L. I. Gilbert). Oxford, UK: Pergamon Press p75- 115.

[56] Merzendorfer H, Zimouch L (2003) Chitin metabolism in insects: structure, function and regulation of chitin synthases and chitinases. J Exp Biol. 206 (24):4393-4412. 